Original Article - Clinical Science

\title{
Nature and incidence of severe limbal stem cell deficiency in Australia and New Zealand
}

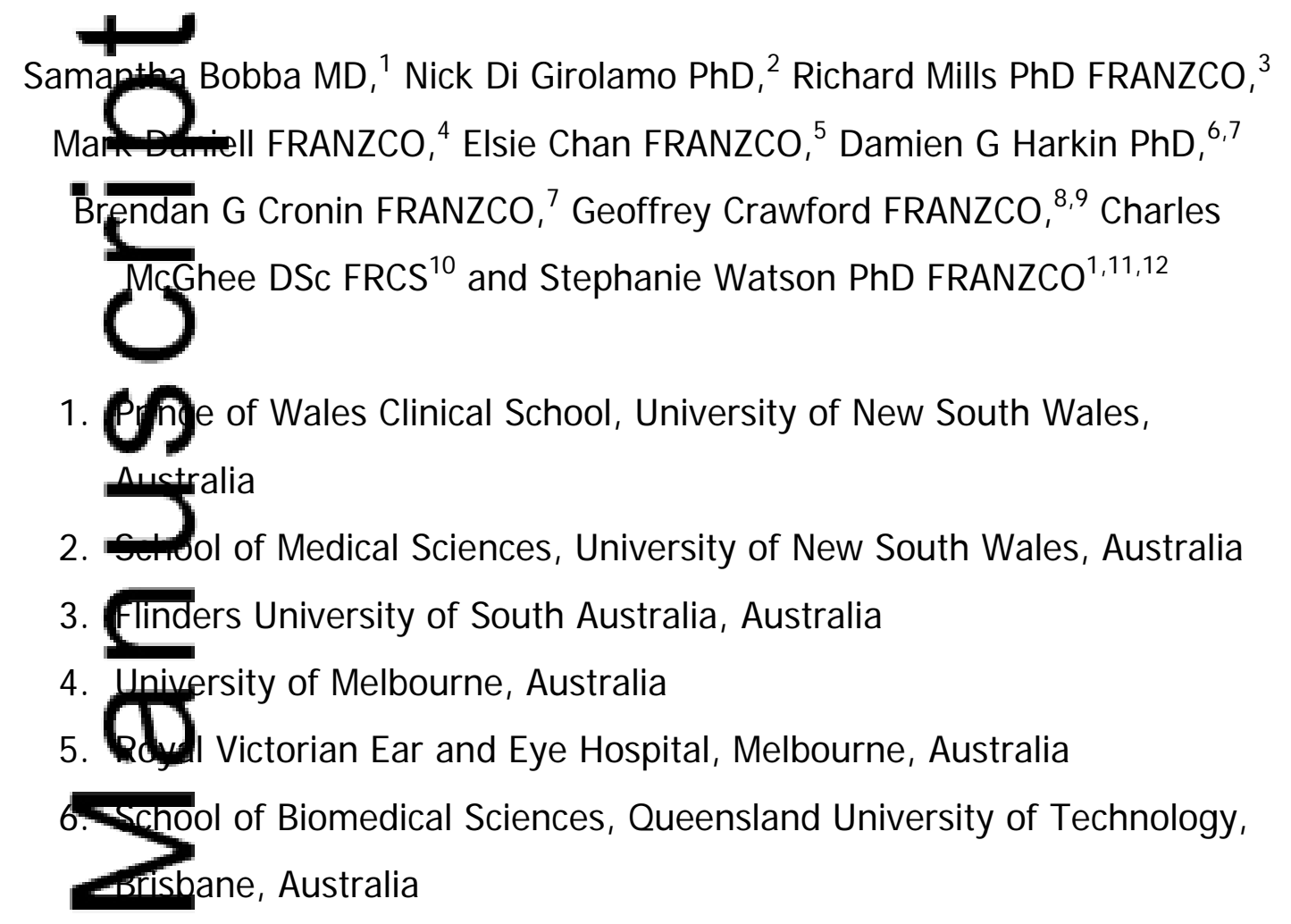

7. Queensland Eye Institute, South Brisbane, Australia

8. Sontre for Ophthalmology and Visual Science, University of Western Australia

9. Lions Eye Institute, Perth, Australia 10 Deartment of Ophthalmology, New Zealand National Eye Centre, Jumersity of Auckland, New Zealand

11. Savg Sight Institute, University of Sydney, Australia

12. Sydney Eye Hospital, Sydney, Australia

This is the author manuscript accepted for publication and has undergone full peer review but has not been through the copyediting, typesetting, pagination and proofreading process, which may lead to differences between this version and the Version of Record. Please cite this article as doi: 10.1111/ceo.12813

This article is protected by copyright. All rights reserved. 
Correspondence: Dr Samantha Bobba, Prince of Wales Hospital, High Street, Randwick, New South Wales, 2031, Australia

Email: Samantha.bobba@gmail.com

Short running title: Incidence of limbal stem cell deficiency

Recerved 23 April 2016; accepted 2 August 2016

Conflid of hterest: None

Fundingevurces: NHMRC Career Development Fellowship for Author SW (APP1Gos24)

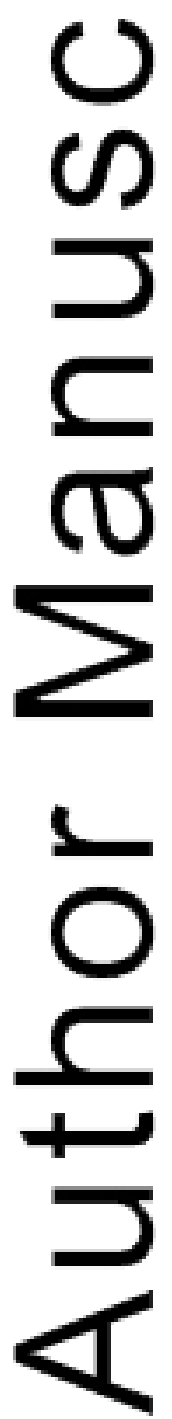

This article is protected by copyright. All rights reserved. 


\section{ABSTRACT}

Background: This study aimed to determine the nature and incidence of severe limbal stem cell deficiency in Australia and New Zealand.

Design: A one-year pilot surveillance study with a one-year follow-up period was conducted in association with the Australian and New Zealand Ophth Imid Surveillance Unit.

Participents: The study included patients reported by practising ophthamologists on the Surveillance Unit's database.

Meth (ds:) Ophthalmologists were provided with a definition of severe limbal stem celleficiency, contacted on a monthly basis by the Unit and asked to report hewly diagnosed cases.

Main Outrome Measures: Severe LSCD was defined as at least 6 clock hours orl-like epitheliopathy, an opaque epithelium arising from the limbus, rate fluorescein staining of the involved epithelium, and superficial corned (1) vascularisation or conjunctivalisation.

Resulan average, 286 report cards were sent by the Surveillance Unit to practisingophthalmologists each month (total 3429 over 12 months) and the Unit received an average of 176 responses per month (total 2111; 62\% resporse rate). During the 1-year study period from April 2013-March 2014, 14 positivg cases were reported to the Unit. A range of underlying aetiologies were in inteded, with contact lens over-wear and cicatrising conjunctivitis being he most common $(n=3)$.

Conclusions: This surveillance study is the first worldwide to document the incide fimbal stem cell deficiency, however due to study design limitations, it is likely to have been under-reported. It provides novel data on the erm graphics, clinical conditions and management of patients with limbal stem cell deficiency as reported by treating ophthalmologists. 
Keywords: epidemiology, eye diseases, stem cells

\section{NTRODUCTI ON}

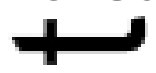

The coner surface is continuously renewed by epithelial stem cells that reside limbus. Depletion of limbal epithelial stem cells (LESCS) or damagtheir niche microenvironment can induce a condition known as limbal stem cell deficiency (LSCD). LSCD may present unilaterally or bilaterally, can be pryial or total, and has a range of acquired and hereditary aetiologies ${ }^{1}$. The disease is characterised clinically by recurrent epithelial defects and chronic pais, secondary to an inability to renew the corneal epithelium². Other featuremade conjunctivalisation, which involves corneal invasion by a vascularised pannus of conjunctival tissue leading to corneal opacity and loss of visininsevere cases ${ }^{3}$.

The modeommonly reported causes of LSCD are chemical and thermal burns $(75 \%)$, followed by ocular surface inflammatory diseases $(7.8 \%)$ such as Stevers J ohnson syndrome and ocular cicatricial pemphigoid ${ }^{4,5,6}$. Other aetiologieg include contact lens over-wear ${ }^{7}$, chemotherapy, iatrogenic injury, ultravidradiation and microbial infection ${ }^{2}$. Aniridia, a hereditary cause of LSCD Ue to oculogenic mutations, is typically characterised by iris hypoplasia, though cases with minimal iris change have been reported ${ }^{8,9}$.

Due totis various aetiologies and the lack of a clinical framework for diage os 1 , the incidence of LSCD remains elusive. Extrapolating data from the most common causes, Shortt and colleagues estimated an incidence of 
approximately 240 cases per annum in the United Kingdom (equivalent to $3.81 \times 10^{-6}$ cases per million, per annum) ${ }^{10}$. Our surveillance study, however, is the first to directly investigate the incidence of LSCD. Determining the incidence and geographical distribution of this heterogenous disease may enable clinicians to establish specialist health networks relative to patient distribution, allowing efficient management strategies. Importantly, the survei anc study offers a comparison between how ophthalmologists diagnond manage LSCD in practice and what the literature recommends. Furthere there is potential to establish such a study internationally, allowi(g fo geographical comparisons and analysis.

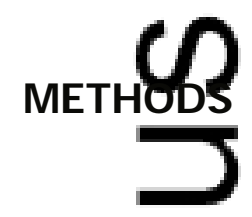

Data pllection

Initial androllow-up questionnaires to investigate the incidence of severe LSCD (ve developed for completion by participating ophthalmologists. Both quectionnires (Appendix I, Appendix II) received input from senior leading ophthalmotogists and senior ocular scientists across five states in Australia and New Zealand. Severe LSCD was defined and characterised by; at least 6 clock hours of whorl-like epitheliopathy, an opaque epithelium arising from the limper late fluorescein staining of the involved epithelium, and superficial neovasurisation or conjunctivalisation ${ }^{7,8,11,12,13}$. The initial questionnaire (No. 1 requested patient demographics including; age, sex, and postcode, as well as date of diagnosis, how the diagnosis was made, investigations performed other ocular disease, the underlying diagnosis, $\mathrm{CL}$ wear, previous limbal grarts, medical, drug and surgical history, and any treatment initiated afteria yosis. The second component of Questionnaire No. 1 focused on clinical signs at the most recent examination, and requested information on 
best-corrected visual acuity, keratopathy, lids and lashes, conjunctival inflammation, symblepharon formation, tear film and ocular surface changes. Questionnaire No. 2 was developed as a follow-up document with the intention of sending it to ophthalmologists 12 months after the study onset. It included similar details as well as provision for entries on changes to the underlying diagnosis, new investigations performed and changes to treatment (topicdand systemic).

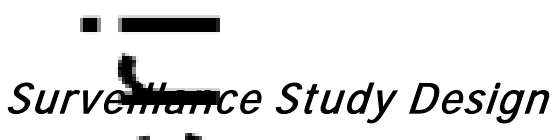

The su(veil)ance study was designed as a 1-year pilot study to determine the incidencerf severe LSCD in Australia and New Zealand (population approximately 23 million and 4.5 million respectively), with follow-up data sought 12 nonths after the study onset. The project was conducted through the Ayran and New Zealand Ophthalmic Surveillance Unit (ANZOSU) and commenced in April 2013 with approval from the South Eastern Sydney Local Healtr DSt ict Low/Negligible Risk Committee (SESLHD HREC-13/058). The ANZ associated with the Royal Australian and New Zealand College of Ophthetimologists (RANZCO), and was based on the British Ophthalmic Surveillance Unit. Each month, the ANZOSU aimed to send all practising ophthalmologists in Australia and New Zealand (both private and public) a report fard listing conditions being studied by the unit, which included severe LSCD April 2013. Each month's report card was emailed to ophth Imologists at the end of the following month. Cases of severe LSCD were reported to the ANZOSU who then informed the authors and provided the details for the reporting ophthalmologists. Ophthalmologists were assigneur study number for each case and were contacted to complete the initia qu stionnaire. Questionnaire responses were entered on a proforma in 
an electronic database; information was de-identified, with a random study protocol number assigned to each patient.

Newly diagnosed cases of severe LSCD were reported to the ANZOSU over a 21-month period from April 2013 - December 2014. However, the clinical and demographic data were obtained only from cases reported in the defined study eridd April 2013 - March 2014.

Statistiver Analysis

The pulation incidence per annum was extrapolated from the number of cases repgted during the 21-month period April 2013 - December 2014. Data from the cefined study period April 2013 - March 2014 were used to calculate mean patient age, and frequencies (percentages) were used to represent other patient demographics, the underlying diagnosis, geographical distributurr and diagnostic approach.

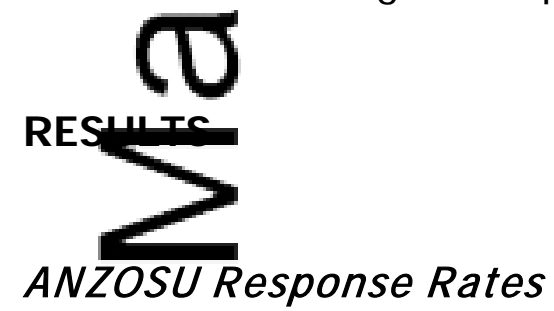

The stydy was conducted during the establishment phase of the Surveillance Unit. Duming this time, on average (mean), 283 report cards were sent to practismgophthalmologists each month (total 3393 over 12 months) and the Unit re ceived an average of 174 responses per month (total 2089; 62\% response rate). By 2015, the ANZOSU had records for 746 ophthalmologists, such tata was included from $38 \%$ of practising ophthalmologists within Austranra and New Zealand.

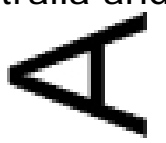


In the 21-month period from April 2013 to December 2014, 26 newly diagnosed cases of severe LSCD were reported to the ANZOSU; this extrapolates to an incidence of 15 cases per year. Fourteen cases of severe LSCD were reported during the defined 1-year study period i.e. from April 2013 to March 2014, coinciding with a 100\% return rate of both questionnaires. At the 1-year follow-up, 4 of these patients had been lost to follow up. Of the 7 ophthalmologists who reported positive cases in the defined 1-year study period; 4 were cornea specialists and 3 were not. Of the 12 ophthalmologists in total that reported positive cases in the 21-month ANZOSU reporting period, 7 were cornea specialists and 5 were not. In terms of the number of cases reported, 12 of the 14 cases in the defined 1-year study period and 22 of the 26 cases in the 21-month reporting period were reported by cornea specialists. Ophthalmologists of other sub-specialities or generalists reported the remaining cases.

\section{Patie tefmographics}

Patiencided in both metropolitan and regional cities, with most cases $(n=7)$ neported in New South Wales, followed by Victoria $(n=5)$ and Queensland $(n=2)$. Although no cases from New Zealand were reported in the defined 1-year study period, 3 of the 26 cases in the 21-month study period were repated in New Zealand. The male to female ratio was 6:7 and the mean dgeat time of diagnosis was $51 \pm 23$ (range, 24 - 87) years.

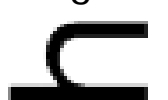

\section{Clinical feptures of patients with LSCD}

In all acts the diagnosis was made on the basis of clinical examination, howeverTinpression cytology was conducted on one patient (case 10), revering goblet cells in the temporal corneal epithelium. Patients had a range of underlying aetiologies, with the most common being $\mathrm{CL}$ over-wear $(n=3)$ 
and cicatrising conjunctivitis $(n=3)$. Patients diagnosed with $\mathrm{CL}$ over-wear reported greater than 10 years of CL-wear, for 8-10 hours per day and 6-7 days per week. Co-existing ocular disease included myopia, glaucoma and cataracts. In managing these patients, $71 \%$ of clinicians reported initiating a combination of topical lubricants and steroids post-diagnosis as first-line therapy, with $21 \%$ prescribing topical lubricants without steroids and 1 clinicidorerorting no medication history. One patient (case 2) received an autologissue graft, performed within 2 weeks of diagnosis. The ocular charactictics, results of clinical examination and management of reported cases Gre Summarised in Tables 1-3.

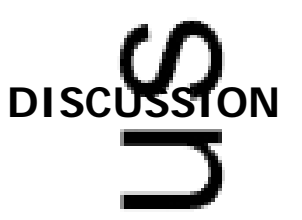

To our wedge, this surveillance of severe LSCD is the first worldwide to attemptodocument its incidence, ocular characteristics and geographical distrib titif The most common aetiologies of LSCD reported were CL-overwea 2104 , cicatrising conjunctivitis (21\%) and chemical/thermal injury (14\%) This is consistent with published reports which suggest chemical/thermal injury, Stevens-J ohnson Syndrome, aniridia and ocular cicatricial pemphigoid are the most common causes ${ }^{2-4}$. Contact lens over-wear has alspen recognised more recently as a cause of LSCD ${ }^{7}$.

The dignosis of patients in this study was primarily based on clinical examination. Interestingly only one ophthalmologist reported performing impresion cytology, which has been considered the gold standard for diagnosing this disease $\mathrm{e}^{2,4}$. In this case the typical clinical features of LSCD were are sent. Overall however, this is consistent with other studies that suggest impression cytology is an unnecessary painful procedure associated 
with the risk of epithelial defects without offering a significant diagnostic advantage $^{11,12}$.

In terms of patient demographics, the wide range of ages ( $24-87 \mathrm{yr}$ ) and similar proportion of males and females in our cohort suggests that LSCD could tiffect either sex at any age. Based on the distribution of their respedive bostcodes, subjects resided in both capital cities (33\%) and noncapitistes (67\%), and were distributed between states in a pattern consis revith the relative population size, for example, with most cases report d in New South Wales (population, 7.5 million) and no cases reported in WestemAustralia (population, 2.6 million). Whilst this suggests that referring to specialist centres in major cities remains a satisfactory approach, it is also possible that underreporting in non-metropolitan areas may have confoynded these findings.

Based Orsponses received during the 21-month period April 2013 Decerasere 2014, the incidence of severe LSCD was extrapolated to 15 cases per annum. Assuming a non-biased reporting cohort and given the $38 \%$ inclusion rate and $62 \%$ response rate to the ANZOSU, the incidence of severe LSCD an be further extrapolated from 15 cases per annum to 63 new cases expectedip Australia and New Zealand. Notably however, ophthalmologists involventign the study had significantly higher reporting rates, with $46 \%$ of cases (12 of 26 cases from April 2013 - December 2014) reported by 2 key investipators, both corneal specialists, suggesting that a degree of reporter

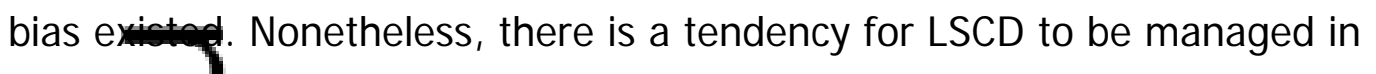
speciailist entres.

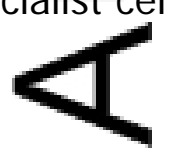


Given the heterogenous nature of LSCD, its varying aetiologies and degrees of severity, Shortt and colleagues (2011) have been the only researchers to estimate the incidence of LSCD thus $\operatorname{far}^{10}$. Based on the relative incidences of its most common aetiologies, they estimated that $10 \%$ of these patients would develop LSCD and predicted an incidence of 240 cases in the United Kingđ̛̃um. Assuming Australia and New Zealand have a similar distribution of LSCD, this equates to approximately 100 new cases per year adjusting for populatize. Notably, our surveillance study focused only on severe LSCD, and thersignificantly lower incidence would be expected. This is consistent with a exyected incidence of 63 new cases as extrapolated by our data. We limited thystudy responses to severe LSCD to reduce reporting bias given the heterogenous nature of LSCD and the difficulty diagnosing the condition, particularly in its early stages of mild vascularisation and surface irregularity. Moreorititis is the severe cases that importantly require inten management and/or surgical therapies such as limbal stem cell transpartofion (LSCT).

Vegumant and colleagues (2015) suggested that 8.9 million people in India were blinded by corneal involvement, based on extrapolations from a population-based study conducted ten years earlier ${ }^{14}$. They predicted that $15-$ $20 \%$ of these patients would benefit from LSCT, indicating a $1.25 \%$ prevale of severe ocular surface disease. It is difficult to compare these figure with our surveillance study for a number of reasons. Firstly, Vegumantirand colleagues provide an indication of prevalence but not incide and the estimation of $15-20 \%$ developing ocular surface disease also appears to be based on subjective assessments rather than definitive data litionally, both incidence and prevalence of LSCD are likely increased 
in India given higher rates of industrial/domestic accidents leading to chemical/thermal ocular injuries.

LSCD is unlikely to be treatable by medical management or conventional corneal transplants due to damage to LESCS and the niche micróenvironment ${ }^{3,15,16}$. Interestingly, in the cases reported in our study, 93\% of tredting bohthalmologists managed patients conservatively with topical lubricand/or steroids in the first year of treatment. This suggests that in practiceating ophthalmologists prefer conservative approaches at least in the fir year following diagnosis, despite evidence indicating that LSCD is

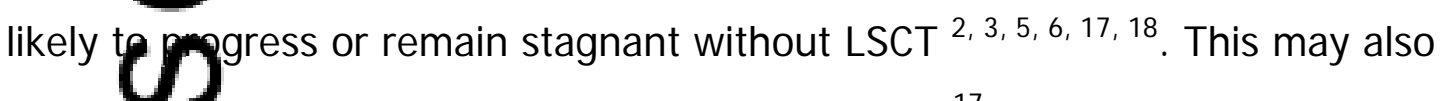
reflect the lack of access to LSCT or LESC therapies ${ }^{17}$. $\longrightarrow$

The stimitation was the 38\% inclusion rate of practising ophthanmorogists ( 246 report cards sent on average each month out of 746 potentand the 62\% response rate to the ANZOSU's monthly emails. In the prelimyears of the study, the ANZOSU was still obtaining accurate contact details for a number of ophthalmologists, explaining the low inclusion rate. Unfortunately, poor response rates are a limitation of many surveillance studie given their non-compulsory and time-consuming nature. Notably, as a RANZCP-ffiliated surveillance unit, the ANZOSU is likely to have had higher respon ates than the alternative option of investigators directly contacting ophth Imologists. Another limitation of the study was delays in receiving the questionnaires mailed to ophthalmologists and occasional missing data as evideneedin Table 1. Repeating the study with a more established surveifrance unit may yield higher response rates. Whilst the incidence of othey -related diseases has been successfully documented (Leske et al., 
2001; Klein et al., 1997), this has typically been done via large-scale longitudinal studies, less feasible in the case of LSCD given its rarity.

Despite the challenges inherent in non-compulsory surveillance reporting, this study provides useful preliminary data on the incidence and nature of severe LSCD, and does so via direct reporting of cases. Given the relatively specialised)field, recruiting more ophthalmologists that specialise in LSCD as investigars may increase reporting rates in future studies. A longer duration of sunturnce could further improve reporting rates as familiarity with the study (ncr)ases. Utilising electronic surveillance forms rather than paper versiops alsy also increase clinician involvement by reducing the time delay between reporting and data collection. There is scope to also implement a similar study in other countries, allowing for comparative analysis.

Acknowividgements

Austrafond New Zealand Ophthalmic Surveillance Unit

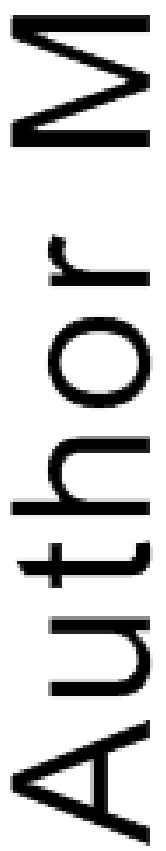




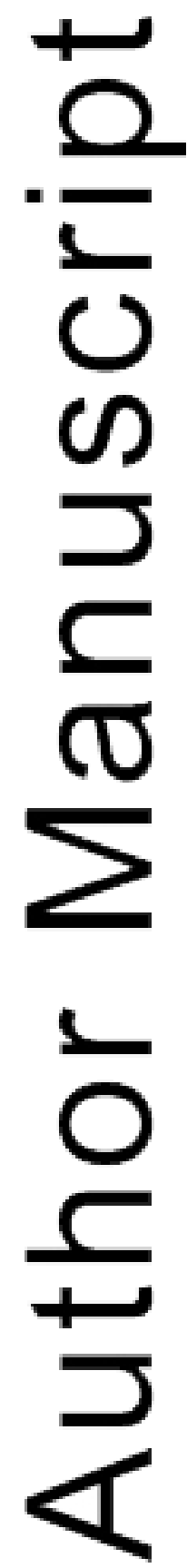

This article is protected by copyright. All rights reserved. 


\section{REFERENCES}

1. Dua H, Miri A, Said D. Contemporary limbal stem cell transplantation - a review. Clin Exp Ophthalmol 2010;38:104-117.

2. Sejpal K, Bakhtiari P, Deng S. Presentation, diagnosis and management of tIImbal stem cell deficiency. Middle East Afr J Ophthalmol 2013;20:5.

3. Sholt A, Tuft S. Ocular surface reconstruction. Br J Ophthalmol 2011; 7:901-

4. Lerytis O, Figueiredo F, Henein C, Lako M, Ahmad S. 13 years of cultured (imbl epithelial cell therapy: a review of the outcomes. J Cell Biochem 2077);12:993-1002.

5. Shortt A, Secker G, Munro P, Khaw P, Tuft S, Daniels J. Characterization of the mbal epithelial stem cell niche: novel imaging techniques permit in vivo beervation and targeted biopsy of limbal epithelial stem cells. Stem Cells zov; 25:1402-1409.

6. STOft A, Secker G, Notara M et al. Transplantation of ex vivo cultured limbal pithelial stem cells: a review of techniques and clinical results. Surv eptrithalmol 2007;52:483.

7. Chan C, Holland EJ : Severe limbal stem cell deficiency from contact lens wear: patient clinical features. Am J Ophthalmol 2013; 155:544-549.

8. HS, Azuara-Blanco A: Limbal stem cells of the corneal epithelium. Surv Equithalmol 2000;44:415-425.

9. Skeens HM, Brooks BP, Holland EJ. Congenital aniridia variant: minimally abnormal irides with severe limbal stem cell deficiency. Ophthalmology 2017; 118: 1260-4.

10.5moftt A, Tuft S, Daniels J. Corneal stem cells in the eye clinic. British medical olletin 2011;100:209-225. 
11. Rama P, Matuska S, Paganoni G et al: Limbal stem-cell therapy and long-term corneal regeneration. N Engl J Med 2010;363:147-55.

12. Rama P, Bonini S, Lambiase A et al. Autologous fibrin- cultured limbal stem cells permanently restore the corneal surface of patients with total limbal stem cell deficiency. Transplantation 2001;72:1478-1485.

13!'Bobba S, Chow S, Di Girolamo N, Watson S: Clinical outcomes of xeno-free exp.nsion and transplantation of autologous ocular surface epithelial stem

- via contact lens delivery: a prospective case series. Stem Cell Res 4 Timerapy 2015; 6:1-14.

14 Ven Iganti GK, Sangwan VS. Interview: Affordability at the cutting edge: cell therapy for ocular surface reconstruction. Regen Med. 2010;5;337-

15. Ken on K, Tseng S. Limbal autograft transplantation for ocular surface ciserders. Ophthalmology 1989;96:709.

16.ecmevarria T, Di Girolamo N. Tissue-regenerating, vision-restoring corneal entit) elial stem cells. Stem Cell Rev Rep 2011;7:256-268.

Davin DG, Apel AI, Di Girolamo N et al. Current status and future prospects feultured limbal tissue transplants in Australia and New Zealand. Clin Exp Ophthalmol 2013;41:272-81.

18 Pellegrini G, Rama P, Rocco A et al. Concise Review: Hurdles in a Successful (xayple of Limbal Stem Cell $\square$ based Regenerative Medicine. Stem Cells

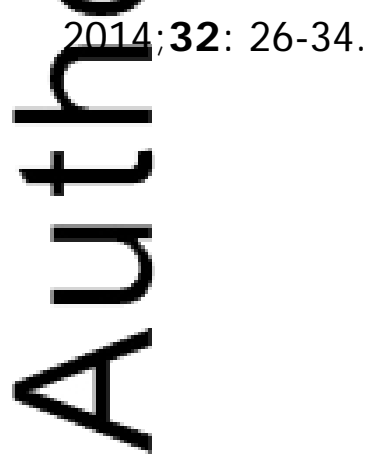


TABLS

-

Tablet1: Demographics and aetiology of reported cases of severe LSCD in Australia and New Zealand (April 2013 - March 2014)

()

\begin{tabular}{|c|c|c|c|c|c|c|c|}
\hline Case & $\begin{array}{l}\text { Geographical region of } \\
\text { patient }\left(5 / e_{j} \text { jence }\right.\end{array}$ & $\begin{array}{l}\text { Sex } \\
\text { (Male/ } \\
\text { Female) }\end{array}$ & $\begin{array}{l}\text { Age at } \\
\text { diagnosis }\end{array}$ & $\begin{array}{l}\text { Method of } \\
\text { diagnosis }\end{array}$ & $\begin{array}{l}\text { Duration of } \\
\text { symptoms prior to } \\
\text { diagnosis }\end{array}$ & Aetiology & $\begin{array}{l}\text { Co-morbid } \\
\text { ocular disease }\end{array}$ \\
\hline 1 & $\begin{array}{l}\text { Broadmeadeds, Melbourne, } \\
\text { VIC }\end{array}$ & $\mathrm{F}$ & 35 & clinical & 5 years & cicatrising conjunctivitis, SJ S & N/A \\
\hline 2 & Townsv le, QLD & $M$ & 30 & dinical & 2 weeks & chemical/thermal injury & $\mathrm{N} / \mathrm{A}$ \\
\hline 3 & MelboumecoD, VIC & $M$ & 39 & clinical & 6 weeks & CL wear & myopia \\
\hline 4 & Wandorgn inc & $\mathrm{F}$ & 78 & clinical & 6 months & anti-metabolites (MMC), OSSN & OSSN \\
\hline 5 & Port Marquare, NSW & $\mathrm{M}$ & 27 & clinical & $<1$ week & chemical/thermal injury & $\mathrm{N} / \mathrm{A}$ \\
\hline 6 & Wollongong, NSW & $M$ & 79 & clinical & 4 weeks & severe pseudomonas keratitis & $\begin{array}{l}\text { glaucoma, } \\
\text { microbial keratitis }\end{array}$ \\
\hline 7 & Rockhampto, QLD & $M$ & 86 & clinical & $>1$ year & amiodarone-induced & cataract \\
\hline 8 & Parra •מfta Sydney, NSW & $\mathrm{F}$ & 33 & clinical & 4 months & $\begin{array}{l}\text { CL wear, cicatrising } \\
\text { conjunctivitis (atopic } \\
\text { keratoconjunctivitis) }\end{array}$ & $\mathrm{N} / \mathrm{A}$ \\
\hline 9 & $\begin{array}{l}\text { Brighto East, Melbourne, } \\
\text { VIC }\end{array}$ & $\mathrm{F}$ & 61 & clinical & 3 years & $\dagger$ & N/A \\
\hline 10 & 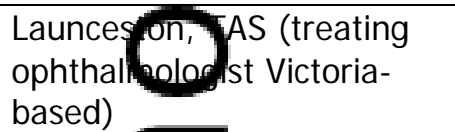 & $\mathrm{F}$ & 57 & $\begin{array}{l}\text { clinical + } \\
\text { impression } \\
\text { cytology }\end{array}$ & 1 year & $\begin{array}{l}\text { CL wear, (family history of } \\
\text { aniridia) }\end{array}$ & $\begin{array}{l}\text { glaucoma, } \\
\text { cataract }\end{array}$ \\
\hline 11 & † (trea ing & $\mathrm{F}$ & 89 & clinical & 3 years & glaucoma medication toxicity & glaucoma, ptosis, \\
\hline
\end{tabular}

This article is protected by copyright. All rights reserved. 


\begin{tabular}{|c|c|c|c|c|c|c|c|}
\hline & $\begin{array}{l}\text { ophthal nologist NSW- } \\
\text { based) }\end{array}$ & & & & & & $\begin{array}{l}\text { blepharitis, } \\
\text { cataract }\end{array}$ \\
\hline 12 & $\begin{array}{l}\text { Woy Wov_ Central Coast, } \\
\text { NSW }\end{array}$ & $\dagger$ & $\dagger$ & clinical & $>1$ year & $\begin{array}{l}\text { cicatrising conjunctivitis } \\
\text { (NB. family history of } \\
\text { ectodermal dysplasia) }\end{array}$ & N/A \\
\hline 13 & North Ryde, Sydney, NSW & M & 43 & clinical & $\dagger$ & $\dagger$ & rosacea keratitis \\
\hline 14 & Mt Druit, Syg ney, NSW & $M$ & 26 & clinical & $\dagger$ & $\begin{array}{l}\text { ectodermal dysplasia (with } \\
\text { family history) }\end{array}$ & N/A \\
\hline
\end{tabular}

\section{(S)}

Legend:-missing data; $\mathrm{CL}$ : contact lens; MMC: mitomycin C; OSSN: ocular surface squamous neoplasia; N/A: not applicable; SJ S: Staveh-J ohnson syndrome
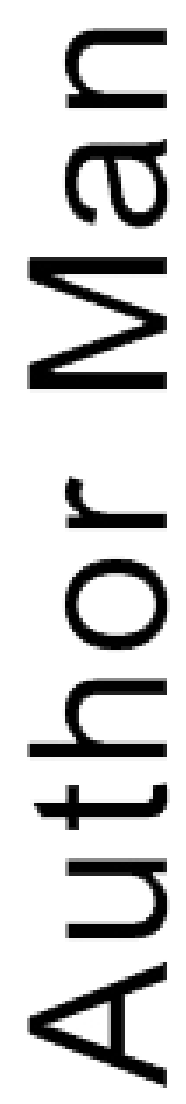

This article is protected by copyright. All rights reserved. 
Table 2:Management of reported cases of severe LSCD in Australia and New Zealand (April 2013 - March 2014)

\begin{tabular}{|c|c|c|c|}
\hline Case & Topical medications prior to diagnosis & $\begin{array}{l}\text { Treatment initiated at } \\
\text { diagnosis }\end{array}$ & Changes to management at the 1-year follow-up \\
\hline 1 & $\begin{array}{l}\text { topical lubricants and steroids, bimatoprost } \\
\text { (Lum gan) brimonidine tartrate/timolol (Combigan) }\end{array}$ & $\mathrm{S}, \mathrm{L}$ & $\begin{array}{l}\text { azithioprine, MMC started and ceased due to compliance } \\
\text { issues }\end{array}$ \\
\hline 2 & $\begin{array}{l}\text { lubricant eyedrops, topical antibiotics; } \\
\text { NB. } r / s t \text { of prior autologous graft }\end{array}$ & $\begin{array}{l}\text { S, L\#, lubricant gel, MMC, oral } \\
\text { vitamin A }\end{array}$ & nil reported \\
\hline 3 & olopatadine (may have precipitated disease) & S\#, L\# & nil reported \\
\hline 4 & MMC (may have precipitated disease) & $\begin{array}{l}\text { S\#, L\#, lubricant gel, lubricant } \\
\text { ointment, MMC ( } 2 \text { cycles) }\end{array}$ & nil reported \\
\hline 5 & nil re & $\begin{array}{l}\text { S\#, L\#, lubricant ointment, oral } \\
\text { doxycycline }\end{array}$ & Amniotic membrane transplantation in the last 12 months \\
\hline 6 & $\begin{array}{l}\text { brinzolamide/timolol (Azarga), bimatoprost } \\
\text { (Lum gy lu' brimonidine tartrate (Alphagan); } \\
\text { NB. }\end{array}$ & L\#, lubricant gel, lubricant ointment & $\begin{array}{l}\text { FML, acetazolamide, dexamethasone topical for PED, } \\
\text { predsol minims; left penetrating keratoplasty } 2013\end{array}$ \\
\hline 7 & nil reported & L\# & nil reported \\
\hline 8 & nil repated & $\begin{array}{l}\text { S\#, L\#, lubricant gel, acetylcysteine } \\
\text { eyedrops, oral doxycycline }\end{array}$ & nil reported \\
\hline 9 & & S\#, L\#, interferon 2beta & $\begin{array}{l}\text { interferon ceased due to improvement, vitamin A started } \\
\text { due to deterioriation }\end{array}$ \\
\hline 10 & nil reported & nil reported & nil reported \\
\hline 11 & $\begin{array}{l}\text { bringlamide (Azopt), lataoprost/timolol (Xalacom) } \\
\text { (may have precipitated disease) } \\
\text { chlor mph nnicol eyedrops (Chlorsig), FML, Lacri-lube }\end{array}$ & $\begin{array}{l}\text { tafluprost (glaucoma therapy with } \\
\text { preservatives ceased), L\# }\end{array}$ & $\begin{array}{l}\text { tafluprost ceased due to inadequate IOP control, } \\
\text { bimatoprost/timolol started }\end{array}$ \\
\hline 12 & lubricuntyedrops & $\begin{array}{l}\text { S\#, S (prednisolone 1\%), L\#, } \\
\text { lubricant gel }\end{array}$ & nil reported \\
\hline
\end{tabular}

This article is protected by copyright. All rights reserved. 


\begin{tabular}{|l|l|l|l|}
\hline 13 & FML & S\#, L\#, oral doxycycline & nil reported \\
\hline 14 & $\begin{array}{l}\text { nil reston } \\
\text { NB, histon of prior deep anterior lamellar keratoplasty }\end{array}$ & S\#, L\#, lubricant ointment & nil reported \\
\hline
\end{tabular}

Legend: †:missing data; CL: contact lens; L: lubricant eyedrops; L\#: preservative-free lubricant eyedrops; MMC: mitomycin C; S: topical steroids; S\#: preservative-free topical steroids

Table Scular examination findings in reported cases of severe LSCD in Australia and New Zealand (April 2013 - March 2014)

(s)

\begin{tabular}{|c|c|c|c|c|c|c|c|c|}
\hline Case & $\begin{array}{l}\text { Affected-av? } \\
\text { (RE/ LE/ BE) }\end{array}$ & $\begin{array}{l}\text { BCVA } \\
\text { (RE) }\end{array}$ & $\begin{array}{l}\text { BCVA } \\
\text { (LE) }\end{array}$ & Keratopathy (RE) & Keratopathy (LE) & $\begin{array}{l}\text { Tear film } \\
\text { (RE) }\end{array}$ & $\begin{array}{l}\text { Tear film } \\
\text { (LE) }\end{array}$ & $\begin{array}{l}\text { Ocular changes at the 1- } \\
\text { year follow-up }\end{array}$ \\
\hline 1 & $\mathrm{BE}$ & LP & $6 / 36$ & total conjunctivalisation & limbitis & $\begin{array}{l}\text { reduced } \\
\text { BUT }\end{array}$ & $\begin{array}{l}\text { reduced } \\
\text { BUT }\end{array}$ & $\begin{array}{l}\text { N/A (no keratinisation } \\
\text { reported) }\end{array}$ \\
\hline 2 & LE & $6 / 6$ & $6 / 9$ & normal & $\begin{array}{l}\text { punctate keratitis, limbitis +/- } \\
\text { peripheral scarring(not axis) }\end{array}$ & $\begin{array}{l}\text { reduced } \\
\text { BUT }\end{array}$ & normal & $\begin{array}{l}\text { similar ocular surface (partial } \\
\text { keratinisation) }\end{array}$ \\
\hline 3 & LE & $6 / 5$ & $6 / 18$ & normal & $\begin{array}{l}\text { punctate keratitis, limbitis }+/- \\
\text { peripheral scarring (not axis) }\end{array}$ & normal & normal & $\begin{array}{l}\text { reduced opacity of ocular } \\
\text { surface }\end{array}$ \\
\hline 4 & $\mathrm{BE}$ & $6 / 9$ & $6 / 36$ & $\begin{array}{l}\text { limbitis +/- peripheral } \\
\text { scarring (not axis), PEDs }\end{array}$ & $\begin{array}{l}\text { history of PED, limbitis +/- } \\
\text { peripheral scarring(not axis) }\end{array}$ & $\begin{array}{l}\text { reduced } \\
\text { BUT }\end{array}$ & $\begin{array}{l}\text { reduced } \\
\text { BUT }\end{array}$ & $\begin{array}{l}\text { improved ocular surface } \\
\text { stability (from partial to no } \\
\text { keratinisation reported) }\end{array}$ \\
\hline 5 & $\mathrm{BE}$ & HM & $\mathrm{LP}$ & limbal ischemia & limbal ischemia - acute signs & dry eye & dry eye & $\begin{array}{l}\text { N/A (no keratinisation } \\
\text { reported) }\end{array}$ \\
\hline 6 & LE & $6 / 9$ & LP & normal & $\begin{array}{l}\text { punctate microbial keratitis, } \\
\text { history of PEDs, limbitis +/- } \\
\text { peripheral scarring (not axis) }\end{array}$ & normal & $\begin{array}{l}\text { reduced } \\
\text { BUT }\end{array}$ & $\begin{array}{l}\text { N/A (no keratinisation } \\
\text { reported) }\end{array}$ \\
\hline 7 & $\mathrm{R}$ & $6 / 12$ & $6 / 9$ & half conjunctivalisation & normal & $\begin{array}{l}\text { reduced } \\
\text { BUT }\end{array}$ & normal & $\begin{array}{l}\text { N/A (no keratinisation } \\
\text { reported) }\end{array}$ \\
\hline 8 & LE & $6 / 6$ & $6 / 18$ & normal & history of PED, limbitis +/- & normal & normal & N/A (no keratinisation \\
\hline
\end{tabular}

This article is protected by copyright. All rights reserved. 


\begin{tabular}{|c|c|c|c|c|c|c|c|c|}
\hline & & & & & peripheral scarring (not axis) & & & reported) \\
\hline 9 & $\mathrm{BE}$ & $6 / 6$ & $6 / 18$ & punctate keratitis & $\begin{array}{l}\text { limbitis }+/- \text { peripheral } \\
\text { scarring(not axis) }\end{array}$ & $\begin{array}{l}\text { reduced } \\
\text { BUT }\end{array}$ & $\begin{array}{l}\text { reduced } \\
\text { BUT }\end{array}$ & $\begin{array}{l}\text { improved ocular surface } \\
\text { stability (from partial to no } \\
\text { keratinisation reported) }\end{array}$ \\
\hline 10 & $\mathrm{BE}$ & $6 / 60$ & HM & total conjunctivalisation & total conjunctivalisation & normal & normal & $\begin{array}{l}\text { N/A (no keratinisation } \\
\text { reported) }\end{array}$ \\
\hline 11 & $\mathrm{BE}$ & $6 / 36$ & $6 / 24$ & punctate keratitis & punctate keratitis & $\begin{array}{l}\text { reduced } \\
\text { BUT }\end{array}$ & $\begin{array}{l}\text { reduced } \\
\text { BUT }\end{array}$ & $\begin{array}{l}\text { reduced opacity/epitheliopathy } \\
\text { of ocular surface }\end{array}$ \\
\hline 12 & $\mathrm{BE}$ & $6 / 12$ & $6 / 45$ & $\begin{array}{l}\text { punctate keratitis, } \\
\text { limbitis }+/ \text { - peripheral } \\
\text { scarring (not axis) }\end{array}$ & $\begin{array}{l}\text { punctate keratitis, limbitis +/- } \\
\text { peripheral scarring (not axis) }\end{array}$ & $\begin{array}{l}\text { reduced } \\
\text { BUT }\end{array}$ & $\begin{array}{l}\text { reduced } \\
\text { BUT }\end{array}$ & $\begin{array}{l}\text { N/A (no keratinisation } \\
\text { reported) }\end{array}$ \\
\hline 13 & $\mathrm{BE}$ & $6 / 12$ & $6 / 9$ & $\begin{array}{l}\text { punctate keratitis, } \\
\text { vascularisation }\end{array}$ & punctate keratitis, limbitis & $\begin{array}{l}\text { reduced } \\
\text { BUT }\end{array}$ & $\begin{array}{l}\text { reduced } \\
\text { BUT }\end{array}$ & $\begin{array}{l}\text { N/A (no keratinisation } \\
\text { reported) }\end{array}$ \\
\hline 14 & $\mathrm{LE}$ & HM & $6 / 6$ & normal & $\begin{array}{l}\text { PEDs, history of microbial } \\
\text { keratitis }\end{array}$ & $\begin{array}{l}\text { reduced } \\
\text { BUT }\end{array}$ & normal & $\begin{array}{l}\text { N/A (no keratinisation } \\
\text { reported) }\end{array}$ \\
\hline
\end{tabular}

(1)

Legend:+t:missing data; BE: both; BUT; break-up time; LE: left; PED: punctate epithelial defect; RE: right

$\longrightarrow$

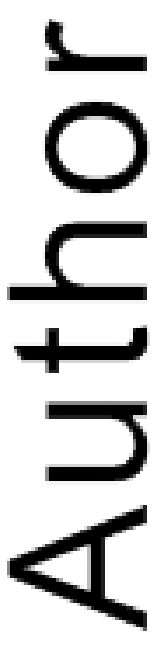

This article is protected by copyright. All rights reserved. 


\section{University Library}

\section{- M I N E R VA}

\section{A gateway to Melbourne's research publications}

Minerva Access is the Institutional Repository of The University of Melbourne

\section{Author/s:}

Bobba, S;Di Girolamo, N;Mills, R;Daniell, M;Chan, E;Harkin, DG;Cronin, BG;Crawford, G;McGhee, C;Watson, S

Title:

Nature and incidence of severe limbal stem cell deficiency in Australia and New Zealand

Date:

2017-03-01

\section{Citation:}

Bobba, S., Di Girolamo, N., Mills, R., Daniell, M., Chan, E., Harkin, D. G., Cronin, B. G., Crawford, G., McGhee, C. \& Watson, S. (2017). Nature and incidence of severe limbal stem cell deficiency in Australia and New Zealand. CLINICAL AND EXPERIMENTAL OPHTHALMOLOGY, 45 (2), pp.174-181. https://doi.org/10.1111/ceo.12813.

Persistent Link:

http://hdl.handle.net/11343/291672 